\title{
PKM PENDAMPINGAN P3BM (PENGEMBANGAN PERANGKAT PEMBELAJARAN BERBASISIS MULTIKULTURAL) BAGI GURU PONDOK PESANTREN MTS AL ASROR DAN SMP AL USWAH SEMARANG
}

\author{
Nimas Puspitasari ${ }^{1 *}$, Atrianing Yessi Wijayanti ${ }^{2}$ \\ ${ }^{1}$ Pendidikan Guru Sekolah Dasar, Fakultas Keguruan dan Ilmu Pendidikan, Universitas Darul Ulum \\ Islamic Centre Sudirman \\ Jl.Tentara Pelajar No.13 Ungaran \\ ${ }^{2}$ Pendidikan Guru Sekolah Dasar, Fakultas Keguruan dan Ilmu Pendidikan, Universitas Darul Ulum \\ Islamic Centre Sudirman \\ J1.Tentara Pelajar No.13 Ungaran \\ *Email: nimaspuspitasari@ymail.com
}

\begin{abstract}
Abstrak
MTs Al Asror dan SMP Al Uswah Semarang merupakan lembaga pendidikan yang berlatar belakang dari pondok pesantren. Secara umum pondok pesantren merupakan lembaga pendidikan yang bersifat prular/ multikultur Siswa dihadapkan dengan situasi perbedaan karakter, pola pemikiran, bahasa dan budaya, dengan demikian perlu adanya penanaman wawasan multikultural agar keadaan tersebut tidak menimbulkan permasalahan sosial. Tujuan dalam kegiatan ini adalah meningkatkan penerapan iptek di masyarakat yaitu pada guru mitra di MTs Al Aror dan SMP Al Uswah berupa pengembangan perangkat pembelajaran berbasis multikultural.Metode yang akan dilaksanakan adalah melakukan (1) Analisa awal/ analisa kebutuhan, mitra, (2) Proses persiapan (3) Proses pelaksanaan yaitu pelatihan dan pendampingan. Pelatihan diadakan dengan pemberian materi mengenai pembelajaran berbasis multikultural, pengidentifikasian materi pembelajaran dan model pembelajaran multikultural. Sedangkan pendampingan dilakukan dalam mengembangkan Perangkat pembelajaran Berbasis multikultural serta Penerapan Perangkat pembelajaran Berbasis multikultural di kelas. Hasil kegiatan yang dicapai antaralain ketercapaian target materi yang diberikan kepada peserta pendampingan, meningkatnya keterampilan guru MTs Al Asror dan SMP AL Uswah dalam mengembangkan perangkat pembelajaran berbasis multikultural dan terlatihnya kemampuan guru dalam menerapkan pembelajaran berbasis multikultural dalam proses pembelajaran di kelas.
\end{abstract}

Kata kunci: Pembelajaran Berbasis Multikultural, Pengembangan Perangkat Pembelajaran

\section{PENDAHULUAN}

Dunia pendidikan sedang berkembang lembaga pendidikan yang berbasis agama. Pondok pesantren merupakan salah satu jenis pendidikan islam di Indonesia yang bertujuan untuk mendalami ilmu agama islam (Hablunminallah) dan mengamalkannya sebagai pedoman hidup keseharian dengan menekankan pentingnya moral dalam hidup bermasyarakat (Hablunminannas). Dewasa ini selain dalam bidang agama pondok pesantren juga menaungi lembaga pendidikan umum. Seperti halnya di pondok pesantren Assalafy Al Asror yang beralamat di Jl. Legok sari raya No. 02, Patemon, Kecamatan Gunung Pati Kota Semarang, selain para santri belajar agama disana juga mereka mengikuti pendidikan umum. Pondok pesantren tersebut menaungi lembaga pendidikan tingkat MTs Data siswa dapat dilihat dengan tabel berikut ini.

Tabel 1. Data Siswa MTs Al Asror

\begin{tabular}{|l|l|l|l|l|l|l|l|l|l|l|l|l|l|l|l|l|l|l|l|}
\hline \multirow{2}{*}{ No } & \multirow{2}{*}{ Asal Daerah } & \multicolumn{4}{|c|}{ Kelas VII } & \multicolumn{4}{|c|}{ Kelas VIII } & \multicolumn{1}{|c|}{ Kelas IX } \\
\hline & & A & B & C & D & E & F & A & B & C & D & E & F & A & B & C & D & E & F \\
\hline 1 & Semarang & 20 & 12 & 23 & 23 & 26 & 12 & 28 & 27 & 17 & 24 & 11 & 20 & 29 & 32 & 24 & 14 & 23 & 19 \\
\hline 2 & Kab. Semarang & 9 & 4 & 3 & 3 & 1 & 3 & 4 & 3 & 9 & 5 & 5 & 3 & 3 & 2 & 1 & 5 & 4 & \\
\hline 3 & Kudus & 2 & & & & & & & & & & & & & & & & & \\
\hline 4 & Grobogan & 2 & 1 & & & & & & 1 & & & 1 & & & & & & & \\
\hline 5 & Demak & 1 & & & & & 1 & & & & & 1 & & 1 & & & 1 & 1 & 1 \\
\hline
\end{tabular}




\begin{tabular}{|c|c|c|c|c|c|c|c|c|c|c|c|c|c|c|c|c|c|c|c|}
\hline \multirow[t]{2}{*}{ No } & \multirow[t]{2}{*}{ Asal Daerah } & \multicolumn{6}{|c|}{ Kelas VII } & \multicolumn{6}{|c|}{ Kelas VIII } & \multicolumn{6}{|c|}{ Kelas IX } \\
\hline & & $\mathrm{A}$ & $\mathrm{B}$ & $\mathrm{C}$ & $\mathrm{D}$ & $E$ & $\mathrm{~F}$ & $\mathrm{~A}$ & $\mathrm{~B}$ & $\mathrm{C}$ & $\mathrm{D}$ & $\mathrm{E}$ & $\mathrm{F}$ & $\mathrm{A}$ & B & $\mathrm{C}$ & $\mathrm{D}$ & $\mathrm{E}$ & $\mathrm{F}$ \\
\hline 6 & Tanggerang & 1 & & 1 & & & & & 1 & & & & & & & & & & \\
\hline 7 & Kendal & 1 & 1 & & & & & 2 & & 3 & & & 1 & & & & 3 & & \\
\hline 8 & Kebumen & & & & & & & & & 2 & & & & & & & & & \\
\hline 9 & Banjarnegara & 1 & & & & & & & & 1 & & & & & & & & & \\
\hline 10 & Pati & 1 & & & & & & & & & & & & & & & & & \\
\hline 11 & Temanggung & 1 & & & & & & & & & & & & & & & & & \\
\hline 12 & Purbalingga & & 1 & & & & & & & & & & & & & & & & \\
\hline 13 & Pekalongan & & 1 & & & & & & & \begin{tabular}{|l|}
1 \\
\end{tabular} & & & & & & & 2 & 3 & \\
\hline 14 & Pemalang & & & & & & & 1 & & & & & & & & & & & \\
\hline 15 & Pacitan & & 1 & & & & & & & & & & & & & & & & \\
\hline 16 & Boyolali & & & & & & & & & & 1 & & & & & & & & \\
\hline 17 & Magelang & & & & & & & & & & 1 & & & & & & & & \\
\hline 18 & Jayapura & & 1 & & & & & & & & & & & & & & & & \\
\hline 19 & Sukabumi & & & 1 & & & & & & & & & & & & & & 1 & \\
\hline 20 & Batang & & & 1 & & & 1 & & & & & & 1 & 1 & & & & & \\
\hline 21 & Jepara & & & 1 & & & & & & & & & & & & & & & \\
\hline 22 & Jakarta & & & 1 & 1 & 1 & & & 1 & & & & & & & & & & \\
\hline 23 & Tegal & & & & & & & & & & & & & 1 & & & & & 1 \\
\hline 24 & Karawang & & & & & & & & & 1 & & & & & & & & & \\
\hline 25 & Cirebon & & & & 1 & 1 & & & & & & & & & & & & & \\
\hline 26 & Bogor & & & & 1 & & & & 1 & & & & & & & & & & \\
\hline 27 & Salatiga & & & & & & 1 & & & & & & & & & & & & \\
\hline 28 & Pontianak & & & & & & 1 & & & & & & & & & & & & \\
\hline 29 & Bangkalan & & & & & & & & & 1 & & & & & & & & & \\
\hline 30 & Banjarmasin & & & & & & & & & & & & 1 & & & & & & \\
\hline & & 39 & 27 & 30 & 29 & 29 & 19 & 35 & 34 & \begin{tabular}{|l|}
37 \\
\end{tabular} & 32 & 18 & 26 & 35 & 36 & 27 & 25 & 33 & 21 \\
\hline
\end{tabular}

Sama halnya dengan pondok pesantren AL Uswah yang berada di Jalan Mr. Koesbiono Tjondro Wibowo, Pakintelan, Gunungpati, Kota Semarang. Pondok pesantren ini yang menaungi lembaga pendidikan SMP. Siswa tersebut berasal dari berbagai daerah. Data siswa dapat dilihat dengan tabel berikut ini:

Tabel 2. Data Siswa SMP AL-Uswah

\begin{tabular}{|l|l|l|}
\hline Kelas & Asal Daerah & Jumlah Siswa \\
\hline VII & Kabupaten Semarang & 9 \\
\hline & Semarang & 19 \\
\hline & Demak & 1 \\
\hline & Bekasi & 1 \\
\hline JUMLAH SISWA & 30 \\
\hline VIII & Kabupaten Semarang & 7 \\
\hline & Semarang & 11 \\
\hline & Kabupaten Grobogan & 1 \\
\hline & Wonosobo & 1 \\
\hline & Brebes & 1 \\
\hline & Pulau Pisau & 1 \\
\hline & Blitar & 1 \\
\hline & Yogyakarta & 1 \\
\hline JUMLAH SISWA & 24 \\
\hline IX & Semarang & 12 \\
\hline & Kabupaten Semarang & 2 \\
\hline & Demak & 2 \\
\hline & Kendal & 1 \\
\hline
\end{tabular}




\begin{tabular}{|l|l|l|}
\hline Kelas & Asal Daerah & Jumlah Siswa \\
\hline & Bekasi & 1 \\
\hline & Nunukan & 1 \\
\hline \multicolumn{2}{|l}{ JUMLAH SISWA } & 21 \\
\end{tabular}

Kedua SMP mitra tersebut berlatarbelakang pondok pesantren, dimana Secara umum pondok pesantren merupakan lembaga pendidikan yang bersifat prular/ multikultur Siswa dihadapkan dengan situasi perbedaan karakter, pola pemikiran, bahasa dan budaya. Perbedaan budaya ini dapat memicu adanya permasalahan- permasalahan sosial sehingga perlu adanya kesadaran perbedaan dan toleransi antar siswa. Seperti halnya menurut Mashadi, Imron (2009) pendidikan multikultural adalah proses penanaman cara hidup menghormati, tulus, dan toleran terhadap keanekaragaman budaya yang hidup di tengah-tengah masyarakat plural.

Dalam proses pembelajaran dalam pendidikan umum di sekolah mitra belum diterapkan pemahaman wawasan mengenai multikultural. Dimana pemahaman multikultural sangat penting sebagai bekal siswa dalam kegiatan sehari- hari dan sebagai santri di pondok pesantren. untuk dapat mengenal budaya lain dan menerima perbedaan dari budaya lain. Proses pembelajaran yang selama ini berjalan masih bersifat transfer ilmu saja, belum disisipinya wawasan multikultural, dan guruguru jarang melaksanakan pelatihan pembuatan perangkat pembelajaran, terutama perangkat pembelajaran berbasis multikultural. Sehubungan dengan hal tersebut di atas, perlu adanya pendampingan dalam pembuatan perangkat pembelajaran berbasis multikultural pada guru mitra di MTs Al Asror dan SMP Al Uswah.

\section{METODE}

Langkah-langkah yang dilakukan untuk mencapai tujuan dan sasaran kegiatan ini akan diadakan pendekatan kepada pihak terkait yaitu pengelola pondok pesantren dan pengelola di sekolah yang dinaunginya dengan mengadakan pelatihan dan pendampingan. Perlu adanya kerjasama dengan guru-guru dalam melaksanakan pengembangan perangkat pembelajaran berbasis multikultural. Model perencanaan kegiatan yang akan dilaksanakan dapat dijelaskan dengan Desain Ipteks pengabdian berikut ini.

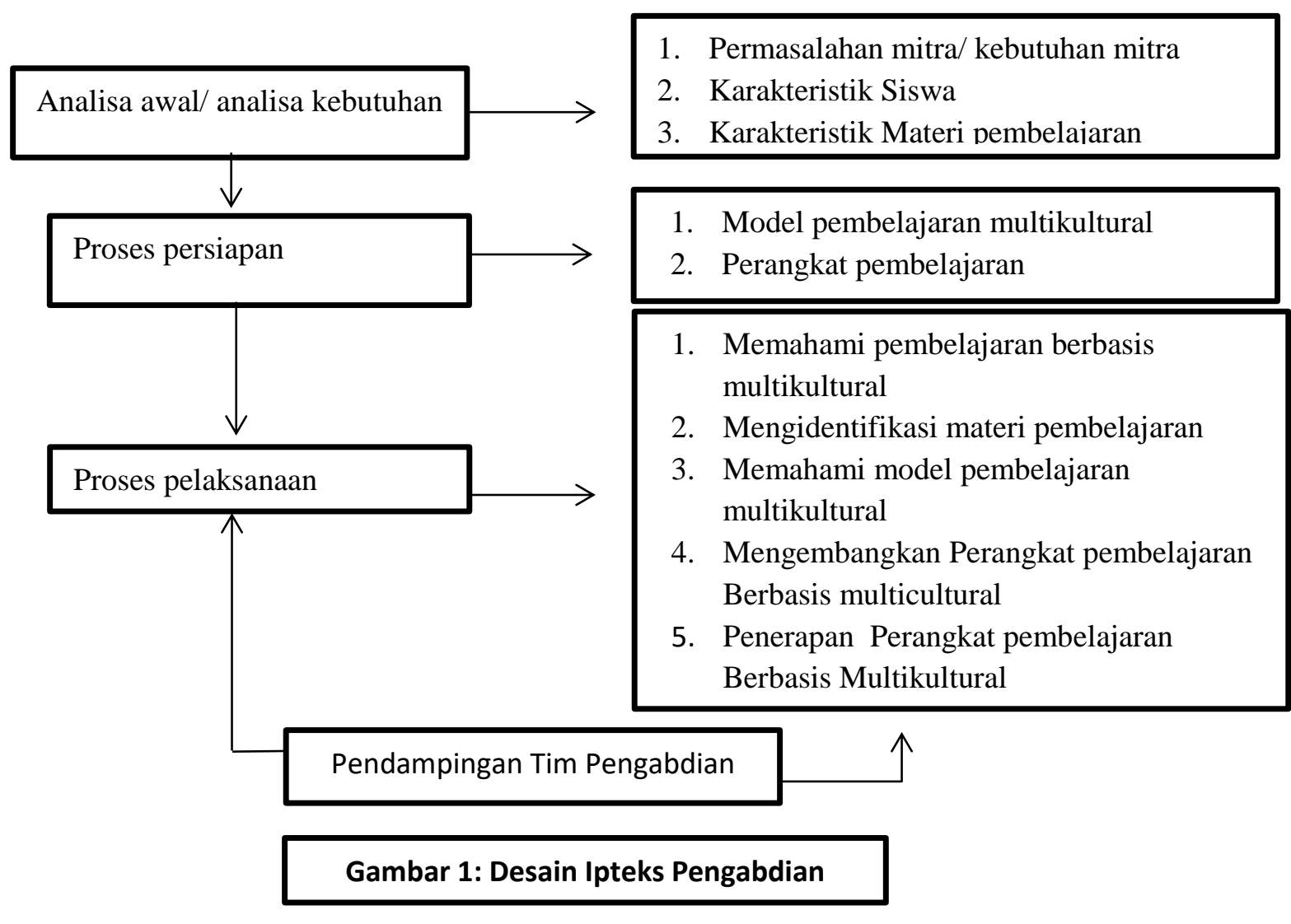


Mekanisme Pelaksanaan Kegiatan

Kegiatan pengabdian ini dilaksanakan dengan beberapa tindakan diantaranya sebagai berikut:

a. Perencaaan

1. Melakukan koordinasi dengan kedua mitra, dalam hal ini adalah Kepala Sekolah MTs Al Asror dan SMP Al Uswah

- Kegiatan ini merupakan koordinasi awal sekaligus survey dalam perencanaan pelaksanaan Pengabdian Kepada Masyarakat. Koordinasi dilakukan antara tim pengabdian dengan pihak mitra yaitu Kepala Sekolah MTs Al- Asror dan SMP Al Uswah untuk mendapatkan persetujuan pelaksanaan kegiatan Pengabdian Pada Masyarakat.

- Melaksanakan wawancara untuk mendapatkan data awal yang nantinya akan dijadikan bahan analisis pelaksaan kegiatan. Dari hasil wawancara di perolah data bahwa belum banyak guru yang mengerti mengenai pembelajaran berwawasan multikultural sehingga belum pernah diterapkan pembelajaran berwawasan multikultural dalam kegiatan KBM. Guru- guru jarang mengikuti kegiatan pelatihan pembuatan perangkat pembelajaran dan belum pernah mengembangkan perangkat pembelajaran berbasis multikultural. Data mengenai siswa dapat dilihat bahwa siswa berasal dari daerah yang berbeda - beda, sehingga kebudayaan yang berkembang di lembaga pendidikan tersebut juga beranekaragam.

- Hasil koordinasi dengan kepala sekolah, disepakati kegiatan dilaksanakan di MTs Al- Asror dengan fasilitas ruang kelas, sound system dan LCD yang dianggap sudah memenuhi untuk melaksanakan pelatihan.

2. Sosialisasi Kegiatan Pengabdian kepada kedua mitra.

- Sosialisasi pelaksanaan pengabdian di konfirmasikan kepada wakil kepala sekolah bidang kurikulum. Dari hasil wawancara diperoleh data bahwa guru belum mengembangkan pembelajaran berbasis multikultural. Kurikulum yang diterapkan belum semuanya menggunakan Kurikulum 2013, masih ada yang menggunakan kurikulum KTSP.

- Mengkoordinasikan jadwal kegiatan pengabdian.

Koordinasi jadwal kegiatan Pengabdian Kepada Masyarakat dilakukan setelah tim pengabdian membuat rancangan kegiatan kemudian di koordinasikan dengan pihak mitra, hal ini bertujuan agar jadwal pelaksanaan dapat diikuti oleh semua peserta pengabdian dengan menyesuaikan jadwal kegiatan di sekolah mitra. Jadwal kegiatan pengabdian dikoordinasikan dengan wakil kepala sekolah bidang kurikulum dan nantinya akan disosialisasikan hasilnya kepada guru mitra pengabdian.

3. Penyusunan program pengabdian berdasarkan hasil analisis situasi, analisis siswa, dan kebutuhan guru mitra

Berdasarkan data yang diperoleh dari koordinasi dan wawancara terhadap kedua mitra tersebut serta hasil observasi, tim pengabdian melakukan analisis baik dari faktor guru, siswa dan situasi untuk menentukan materi pengabdian agar sesuai dengan kebutuhan kedua mitra.

Hasil analisis siswa diperoleh data bahwa :Siswa yang berasal dari kota, cenderung memiliki sifat egois, kurangnya rasa toleransi dengan teman yang lain serta Ingin menguasai lingkungan. Namun karena sudah terbiasa dengan teknologi yang modern, kemampuan dalam penguunaan teknologi lebih baik dibandingkan siswa lainnya. Mereka lebih berani dan percaya diri dalam mengungkapkan pendapat. Sedangkan siswa yang berasal dari daerah, sebagian besar mereka lebih dapat menghargai perbedaan, memliki rasa toleransi, dapat diatur. Tetapi mereka cenderung pasif karena kurangnya kepercayaan diri sehingga dalam proses pembelajaran mereka jarang mengajukan pendapat.

Hasil analisis guru diperoleh bahwa sebagian besar guru tidak memahami pembelajaran berbasis multikultural dan bagaimana cara pengembangannya sebagai model pembelajaran. Dengan demikian materi yang akan disampaikan dalam pengabdian ini meliputi pembelajaran berbasis multikultural, identifikasi materi pembelajaran dan model pembelajaran multikultural. Selain menyiapkan materi, tim pelaksanan juga 
melakukan pembekalan kepada mahasiswa selaku tim kegiatan pengabdian untuk mempermudah pelaksanaan pelatihan.

b. Pelaksanaan Tindakan

Pelaksanaan tindakan dilakukan dengan 2 cara yaitu pelatihan dan pendampingan. Kegiatan pelatihan dilakukan 3 tahap bertujuan untuk memberikan pemahaman mengenai pembelajaran berbasis multikultural. Materi yang disajikan dalam pelatihan tersebut antaralain:

1. Pelatihan tentang pembelajaran berbasis multikultural

2. Pelatihan tentang pengidentifikasian materi pembelajaran

3. Pelatihan tentang model pembelajaran multikultural

Pada pelaksanaan pendampingan dilakukan dalam 2 kegiatan diantaranya adalah

1. Pendampingan Mengembangkan Perangkat pembelajaran Berbasis multikultural

2. Pendampingan Penerapan Perangkat pembelajaran Berbasis multikultural

c. Observasi

Kegiatan observasi dilakukan secara langsung oleh tim pengabdian dengan melakukan pengamatan dari kegiatan pelatihan hingga pendampingan penerapan perangkat pembelajaran di kelas. Selain itu tim pengabdian memberikan angket kepada guru mitra untuk melihat tanggapan mengenai kegiatan pengabdian yang telah dilaksanakan. Proses ini dilakukan sebagai bahan evaluasi.

d. Evaluasi

Proses evaluasi dilaksanakan untuk mengetahui kekurangan dan kendala dalam pelaksanaan kegiatan pengabdian.

e. Refleksi

Refleksi dilakukan bersama antara tim pengabdian dengan guru mitra. Hal ini dilakukan untuk mengetahui seluruh proses pelaksanaan kegiatan.

Pelaksanaan Kegiatan pengabdian pengembangan perangkat pembelajaran berbasis multikultural dapat berjalan dengan baik, dengan adanya partisipasi lembaga terkait diantaranya:

1. Pemberian izin kerjasama dari Kepala Sekolah guna bersama melaksanakan kegiatan pengabdian

2. Kesediaan guru dalam melaksanakan pelatihan pengembangan perangkat pembelajaran berbasis multikultural.

3. Kesediaan guru dalam melaksanakan kegiatan pendampingan penerapan pembelajaran berbasis multikultural.

Evaluasi pelaksanaan program pengabdian pada masyarakat "Pendampingan P3BM (Pengembangan Perangkat Pembelajaran Berbasis Multikultural) di MTs Al Asror dan SMP Al Uswah dilaksanakan oleh tim pengabdian dengan melaksanakan pendampingan penerapan proses pembelajaran oleh guru mitra. Rencana tahapan berikutnya yang akan dilaksanakan dalam program pengabdian ini adalah dengan melaksanakan pelatihan berkala dalam pengembangan perangkat pembelajaran berbasis multikultural agar dapat meningkatkan kreativitas dalam menerapkan pembelajaran berbasis multikultural.

\section{HASIL DAN PEMBAHASAN}

\section{Hasil kegiatan}

1. Pelatihan Pembelajaran berbasis multikultural

Kegiatan pelatihan dengan materi Pembelajaran berbasis multikultural disampaikan oleh ibu Atriyaning Yessi Wijayanti,S.Pd.,M.Pd. Kegiatan ini dilaksanakan tanggal 9 Maret 2018 setelah kegiatan upacara pembukaan. Materi ini ditujukan supaya bapak ibu guru memahami bagaimana pembelajaran berbasis multikultural dan apa tujuannya dalam proses pembelajaran perlu adanya penanaman wawasan multikultural pada peserta didik, khususnya sekolah yang berlatarbelakang dari pondok pesantren.

Kegiatan tersebut memberikan warna baru bagi bapak ibu guru peserta pengabdian mengenai pembelajaran berbasis multikultural. Antusias dari peserta dilihat dari interaksi peserta terhadap pemateri dengan mengajukan beberapa pertanyaan. Pertanyaan pertama diajukan oleh bapak Drs. Muhzin, S.Pd Apakah kelebihan dari proses pembelajaran ketika seorang guru 
menerapkan pembelajaran berbasis multikultural. Pertanyaan berikutnya dari Ibu Anindita, S.Pd mengenai pembelajaran berbasis multikultural apakah hanya dapat diterapkan pada sekolahsekolah yang berlatar belakang pondok pesantren.

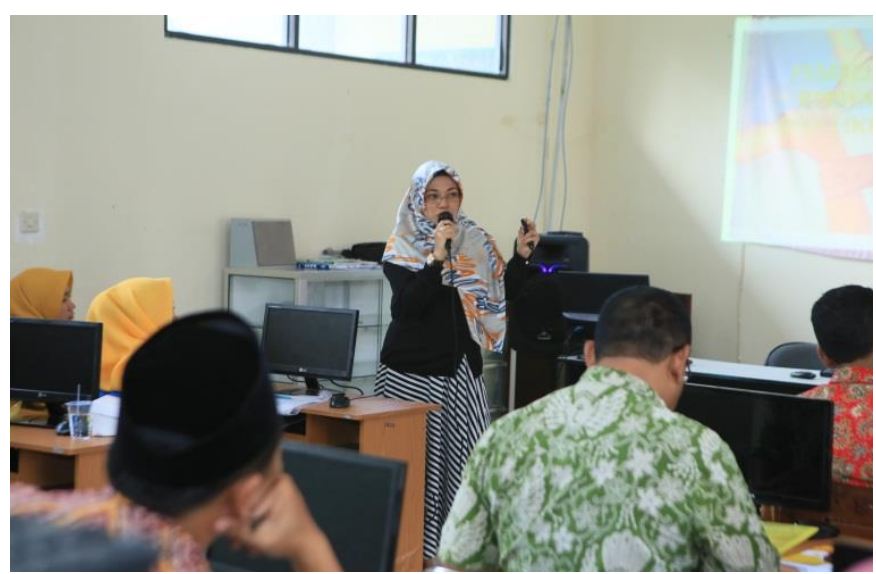

\section{Gambar 2. Ibu Atriyaning Yessi Wijayanti,S.Pd.,M.Pd memaparkan materi pembelajaran berwawasan multikultural}

2. Pelatihan pengidentifikasian materi pembelajaran

Kegiatan Pelatihan dengan mengangkat materi tentang pengidentifikasian materi pembelajaran di paparkan oleh ibu Nimas Puspitasari, S.Pd.,M.Pd. kegiatan ini dilaksanakan pada tanggal 9 Maret 2018. Tujuan dari penyampaian materi tersebut adalah sebagai langkah awal peserta pengabdian dalam mengembangkan perangkat pembelajaran berupa model pembelajaran berbasis multikultural. Interaksi positif dilihat dari keaktifan peserta pengabdian dalam mengajukan pertanyaan yang berkaitan dengan materi sesuai mata pelajaran yang diampu peserta pengabdian. Ibu Martini, S.Pd Mengajukan pertanyaan bagaimana memilih materi jika materi tersebut sifatnya eksak seperti IPA.

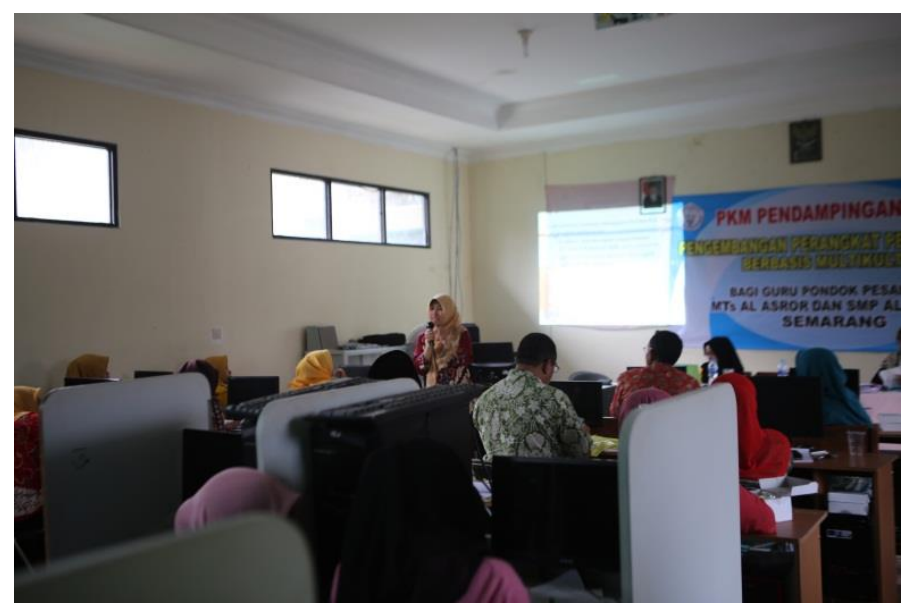

\section{Gambar 3. Ibu Nimas Puspitasari,S.Pd.,M.Pd memaparkan materi identifikasian materi pembelajaran}

3. Pelatihan model pembelajaran multikultural

Kegiatan Pelatihan dengan mengangkat materi tentang model pembelajaran multikultural di paparkan oleh ibu Nimas Puspitasari, S.Pd.,M.Pd. kegiatan ini dilaksanakan pada tanggal 16 Maret 2018. Pada pelatihan ini guru diberikan gambaran mengenai pegembangan model pembelajaran multikultural, apa saja langkah-langkah yang perlu dilakukan dalam penyusunan model pembelajaran berbasis multikultural. Interaksi positif dilihat dari keaktifan peserta pengabdian dalam aktivitas Tanya jawab. Ibu Sri Hartatik, S.Pd mengajukan pertanyaan 
kapan wawasan multikultural dapat disisipkan dalam proses pembelajaran. Sedangkan pertanyaan dari ibu Nur Imroatur R. S.PdI Mengajukan pertanyaan bagaimana cara kita menyesuaikan nilainilai wawasan multikultural dengan materi ajar.

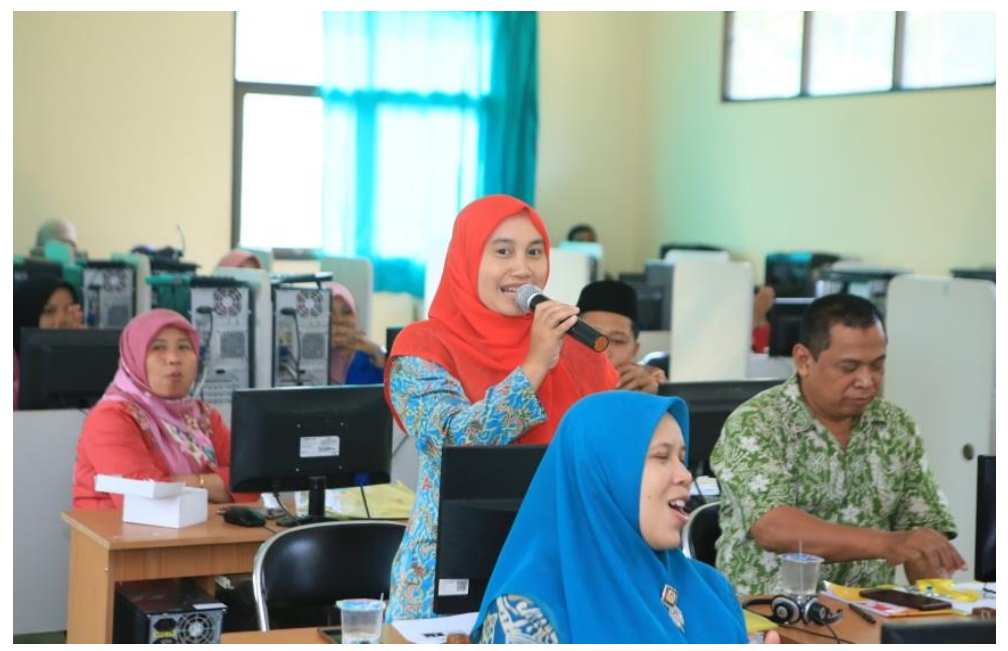

\section{Gambar 4. Ibu Nur Imroatur R. S.PdI sedang mengajukan pertanyaan dalam kegiatan pelatihan}

4. Pendampingan Pengembangkan Perangkat Pembelajaran Berbasis Multikultural

Pelaksanaan kegiatan pelatihan yang diselenggarakan pada tanggal 23 Maret 2018, dihadiri oleh peserta pelatihan yaitu guru mitra MTs Al-Asror dan SMP Al-Uswah, tim pengabdian dan juga mahasiswa selaku panitia kegiatan. Pada kegiatan kali ini dilaksanakan pendampingan dalam penyusunan pengembangan perangkat pembelajaran berbasis multikultural. Kegiatan pendampingan ini dilakukan langsung oleh tim pengabdian yaitu ibu Nimas Puspitasari, S.Pd.,M.Pd dan juga ibu Atrianing Yessi Wijayanti S.Pd.,M.Pd.. Sebelumnya guru mitra sudah ditugaskan untuk membawa buku ajar dan silabus sebagai bahan dalam pembuatan perangkat pembelajaran berbasis multikultural. Kegiatan berjalan dengan lancar dilihat dari antusias bapak ibu guru mitra dalam menyusun perangkat pembelajaran sesuai dengan arahan yang telah disampaikan oleh tim pengabdian

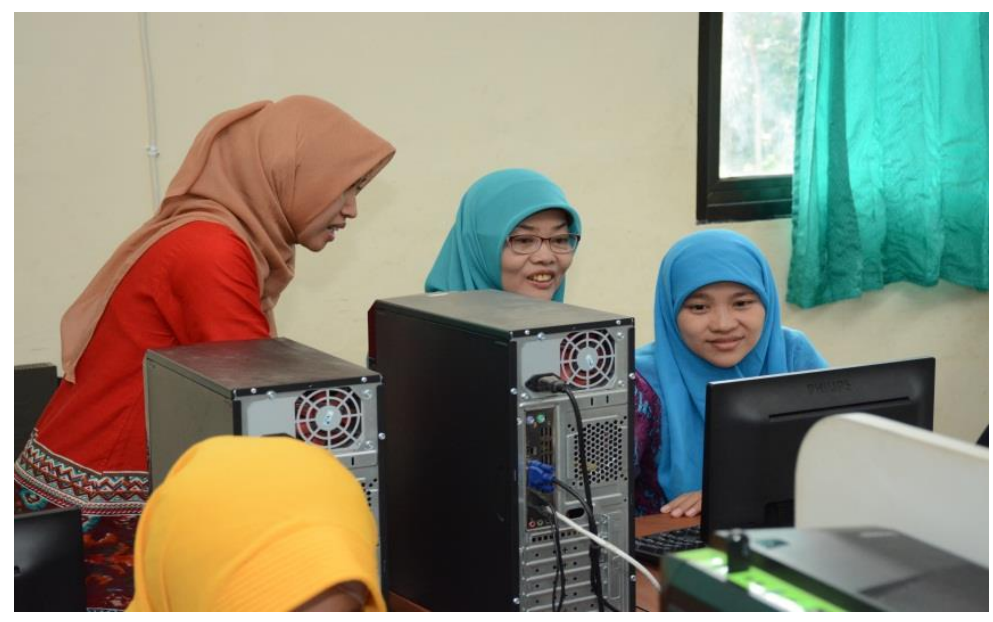

Gambar 5. Tim pengabdian melakukan pendampingan kepada guru mitra dalam menyusun perangkat pembelajaran berbasis multikultural 
5. Pendampingan Penerapan Perangkat pembelajaran di Kelas

Pelaksanaan Pendampingan Penerapan Perangkat Pembelajaran di kelas dilaksanakan dari tanggal 26 Maret - 7 April 2018, Kegiatan ini bertujuan untuk melihat bagaimana guru mitra dalam menggaplikasikan perangkat pembelajaran berbasis multikultural dari awal kegiatan hingga penutup kegiatan pembelajaran. Kegiatan ini dilaksanakan oleh tim pengabdian dan mahasiswa selaku panitia kegiatan dan didampingi oleh wakil kepala sekolah bidang kurikulum.

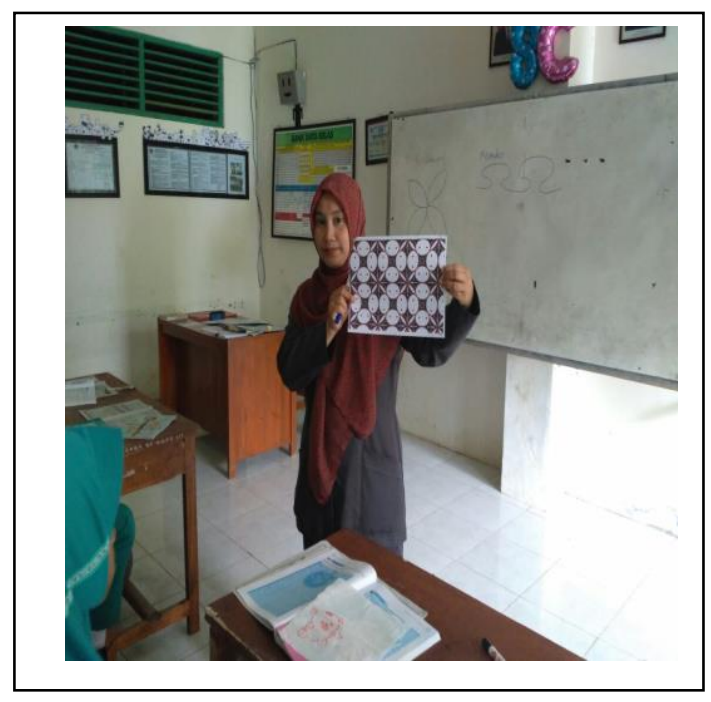

Gambar 6. Guru membangun wawasan multikultural menampilkan contoh corak batik dari beberapa daerah

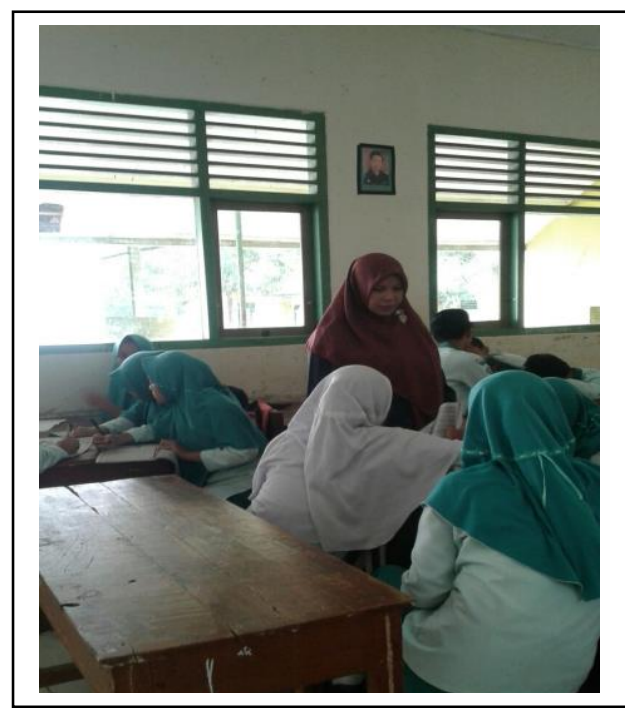

Gambar 7. Guru melakukan bimbingan kepada setiap kelompok agar tercipta rasa saling menghormati pada diri siswa dalam dalam berdiskusi kelommok

\section{Pembahasan}

Selama proses pengabdian, tim pelaksana kegiatan pengabdian melakukan pengamatan baik proses kegiatan dan aktivitas guru mitra sebagai peserta pengabdian. Untuk melihat respon dari peserta kegiatan pengabdian dilakukan dengan angket untuk menilai materi, instruktur dan metode yang digunakan dalam kegiatan pengabdian. Dari hasil angket dapat diketahui bahwa dari seluruh peserta pengabdian tingkat kesesuaian terhadap materi dengan kebutuhan, diperoleh nilai dengan kategori Sangat baik sebesar 88\%, kategori Baik sebanyak $12 \%$, Kategori Cukup baik 0\% dan Kategori Kurang Baik sebanyak 0\%. Sedangkan untuk penilaian terhadap instruktur diperoleh nilai dengan kategori sangat baik 95\%, kategori Baik dengan nilai 5\%, kategori Cukup Baik dengan nilai 0\% dan Kategori Kurang baik dengan nilai $0 \%$. Sedangkan untuk penilaian terhadap metode yang digunakan dalam pengabdian diperoleh nilai dengan kategori sangat baik $92 \%$, kategori Baik dengan nilai $8 \%$, kategori Cukup Baik dengan nilai 0\% dan Kategori Kurang baik dengan nilai 0\%. Lebih jelasnya dapat digambarkan dengan diagram berikut ini: 


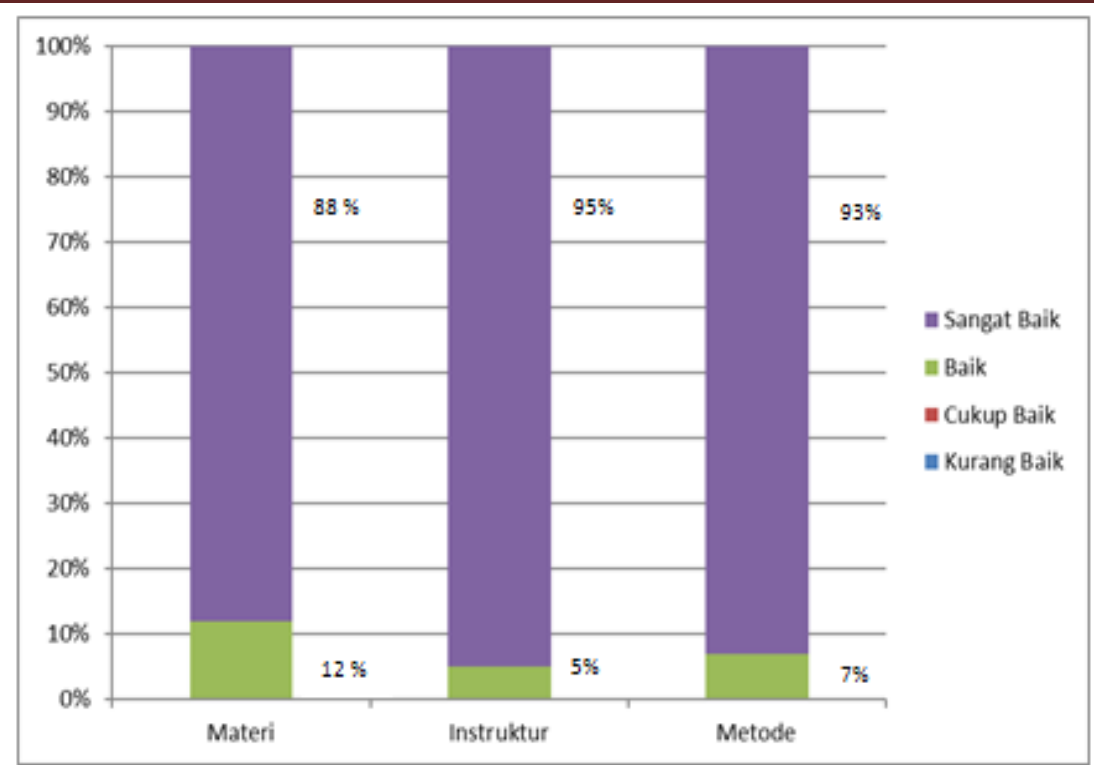

Gambar 8. Diagram Respon Peserta Pengabdian

Penilaian respon dari peserta kegiatan pengabdian secara keseluruhan dapat disimpulkan bahwa tingkat kepuasan terhadap kegiatan pengabdian sangat tinggi. Materi yang disajikan sesuai dengan kebutuhan peserta pengabdian. Dengan lingkungan sekolah berlatarbelakang pondok pesantren dimana banyak adanya keragaman budaya dari siswa sehingga perlu adanya pembelajaran yang dapat menguatkan nilai- nilai budaya dengan diterapkannya pembelajaran berbasis multikultural. Liliweri dalam Nimas (2012) menyatakan bahwa pembelajaran multikultural merupakan strategi pendidikan yang memanfaatkan keberagaman latar belakang kebudayaan dari para peserta didik sebagai salah satu kekuatan untuk membentuk sikap multikultural. Strategi ini sangat bermanfaat, sekurang-kurangnya bagi sekolah sebagai lembaga pendidikan dapat membentuk pemahaman bersama atas konsep kebudayaan, perbedaan budaya, keseimbangan, dan demokrasi dalam arti yang luas. Sehingga diharapkan para generasi penerus menjadi "Generasi Multikultural" yang menghargai perbedaan, selalu menegakan nilai-nilai demokrasi, keadilan dan kemanusiaan yang akan datang. (H.R. Tilaar. 2002)

Guru perlu mengembangkan perangkat pembelajarannya sendiri yang sesuai dengan karakteristik siswa untuk mengoptimalkan kegiatan proses belajar mengajar. Pentingnya pengembangan perangkat pembelajaran tertuang dalam Peraturan Pemerintah Nomor 32 Tahun 2013 yang berkaitan dengan standar proses. Disebutkan bahwa guru diharapkan dapat mengembangkan perencanaan pembelajaran. Dipertegas lagi melalui Permendiknas Nomor 41 Tahun 2007 tentang standar proses, yang antara lain mengatur tentang perencanan proses pembelajaran yang mensyaratkan bagi pendidik pada satuan pendidikan untuk mengembangkan perencanaan pembelajaran. Setiap guru pada satuan pendidikan. berkewajiban menyusun perangkat pembelajaran secara lengkap dan sistematis agar pembelajaran berlangsung secara interaktif, inspiratif, menyenangkan, menantang, memotivasi peserta didik untuk berpartisipasi aktif, serta memberikan ruang yang cukup bagi prakarsa, kreativitas, dan kemandirian sesuai dengan bakat, minat, dan perkembangan fisik serta psikologis peserta didik.

Pendampingan pengembangan perangkat pembelajaran berbasis multikultural diupayakan agar guru nantinya dapat menambah kreatifitas dalam penyusunan perangkat pembelajaran yang disesuaikan dengan kondisi dan karakteristik siswa. Hasil dari penyusunan pengembangan perangkat pembelajaran berbasis multikultural diterapkan secara langsung oleh guru sesuai dengan bidang mata pelajaran masing- masing. Kegiatan ini sekaligus untuk melihat bagaimana keterampilan guru dalam menerapkan pembelajaran berbasis multikultural.

Dari hasil pengamatan yang dilakukan tim pengabdian terhadap penerapan pembelajaran oleh guru mitra bahwa secara keseluruhan guru mitra sudah dapat menerapkan pembelajaran berbasis 
multikultural. Aspek yang diamati dalam kegiatan ini adalah dilihat dari materi, Kompetensi pedagogik, media pembelajaran, Sumber/bahan pembelajaran, Proses Pembelajaran, dan Evaluasi Pembelajaran. Untuk lebih jelasnya dapat digambarkan dengan diagram berikut ini:

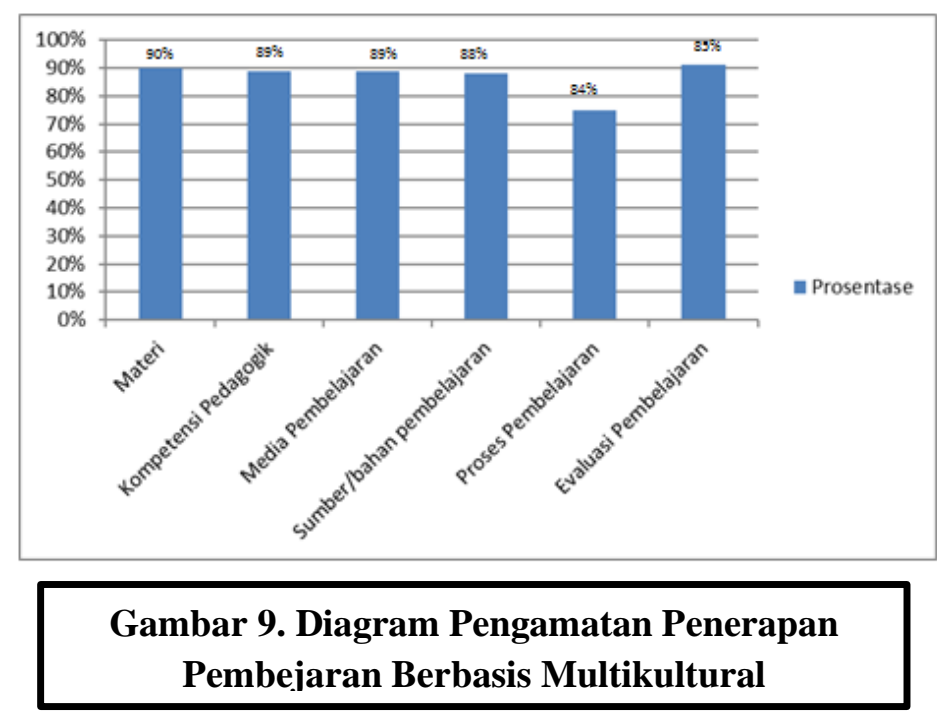

Hasil pengamatan menunjukan bahwa guru dapat menyesesuaikan antara materi dengan wawasan multikultural yang diberikan pada siswa. Seperti yang dijelaskan dalam James A. Banks (1994) dilihat dari dimensi integrasi isi secara khusus, para guru menggabungkan kandungan materi pembelajaran dengan wawasan yang akan di terapkan dalam proses pembelajaran, dan guru mampu dalam mengintegrasi nilai-nilai multikultural dalam pembelajaran. Penggunaan media pembelajaran multikultural mudah digunakan dan dipahami baik oleh guru maupun siswa, Kesesuaian media dengan tujuan belajar Multikultural dan kesesuaian sumber pembelajaran dengan kebutuhan.

Pada kegiatan pembelajaran guru menyisipi nilai - nilai multikultural dalam materi yang disampaikan. Penyampaian materi pembelajaran dengan membangun nilai- nilai budaya pada siswa serta membangun suasana pembelajaran yang partisipatif dan aktif bagi siswa. Zakiyuddin(2005) mengemukakan karakteristik pendidikan multikultural, yaitu a) belajar hidup bersama dalam perbedaan, b) membangun saling percaya, c) memelihara saling pengertian, d) saling menghargai, e) berfikir terbuka, f) apresiasi dan interdependensi serta g) revolusi konflik. Pada pelaksanaan evaluasi pembelajaran bersifat objektivitas.

\section{KESIMPULAN}

Selama proses pengabdian, tim pelaksana kegiatan pengabdian melakukan pengamatan baik proses kegiatan dan aktivitas guru mitra sebagai peserta pengabdian. Adapun hasilnya sebagai berikut:

a. Penilaian respon dari peserta kegiatan pengabdian secara keseluruhan dapat disimpulkan bahwa tingkat kepuasan terhadap kegiatan pengabdian sangat tinggi. Materi yang disajikan sesuai dengan kebutuhan peserta pengabdian diperoleh nilai dengan kategori Sangat baik sebesar 88\%, kategori Baik sebanyak $12 \%$, Kategori Cukup baik 0\% dan Kategori Kurang Baik sebanyak 0\%. Sedangkan untuk penilaian terhadap instruktur diperoleh nilai dengan kategori sangat baik 95\%, kategori Baik dengan nilai 5\%, kategori Cukup Baik dengan nilai $0 \%$ dan Kategori Kurang baik dengan nilai $0 \%$. Sedangkan untuk penilaian terhadap metode yang digunakan dalam pengabdian diperoleh nilai dengan kategori sangat baik 92\%, kategori Baik dengan nilai 8\%, kategori Cukup Baik dengan nilai 0\% dan Kategori Kurang baik dengan nilai $0 \%$.

b. Hasil pengamatan menunjukan bahwa guru dapat menyesesuaikan antara materi dengan wawasan multikultural yang diberikan pada siswa. 


\section{DAFTAR PUSTAKA}

Banks, James A. (1994). An Introduction to Multikultural Education. Boston: Allyn Bacon.

BNSP. Peraturan Menteri Pendidikan nasional Republik Indonesia Nomor 41 tahun 2007 tentang standarProses untuk satuan pendidikan dasar dan menengah

Daryanto dkk. 2014. Pengembangan Perangkat Pembelajaran (Silabus, RPP, PHB, Bahan Ajar). Solo: Gava Media

Hanum, Farida. 2009. Implementasi Model Pembelajaran Multikultural Di Sekolah Dasar Di Propinsi Daerah Istimewa Yogyakarta, Artikel Multikultural-Stranas 2009. Yogyakarta

Mashadi ,Imron, 2009. Pendidikan Agama Islam Dalam Persepektif Multikulturalisme. Jakarta :Balai Litbang Agama

Nafi', M. Dian, dkk, 2007. Praksis Pembelajaran Pesantren, Yogyakarta: Instite for training and development (ITD) Amherst,

Peraturan pemerintah republik indonesia nomor 32 tahun 2013 tentang perubahan atas peraturan pemerintah Nomor 19 tahun 2005 tentang standar nasional pendidikan ( diunduh tanggal

Puspitasari, Nimas. 2012. Pengembangan Model Pembelajaran IPS Berwawawasan Multikultural Berbantuan CD Interaktif Di SMK Bina Nusantara Tahun Ajaran 2011/2012. Semarang: UNNES

Sutarno. 2008. Pendidikan Multikultural. Jakarta: Direktorat Jendral Pendidikan

Tinggi Departemen Pendidikan Nasional.

Syahid Ahmad. 2013. Aplikasi Pembelajaran Berwawasan Multikultural di Sekolah Dasar Muhammadiyah 3. Palu: P3M STAIN Datokarama Palu

Tilaar, HAR. (2002). Perubahan Sosial dan Pendidikan: Pengantar Pedagogik Transformatif untuk Indonesia. Jakarta: Grasindo

Zakiyuddin Baidhawy. 2005. Pendidikan Agama berwawasan multikultural. Yogyakarta: Erlangga 